\title{
Moral Rebellion and Religiusity in Pious Muslim Novels: Chavchay Saifullah and Muhidin M Dahlan Review of Sociology of Literature
}

\author{
Herdi Sahrasad $^{1}$, Muhammad Ridwan ${ }^{2}$ \\ ${ }^{1}$ Senior Lecturer at University of Paramadina, Jakarta, Indonesia \\ ${ }^{2}$ State Islamic University of North Sumatera, Indonesia \\ sahrasad@yahoo.com
}

\begin{abstract}
This article argues that novelists Muhidin M Dahlan and Chapchay Syaifullah tried to make moral and religious rebellions in their work as a result of existing social conditions. They rebel against normative and established values, old order and social arrangements. They are creative in the context of literature as a fictional world built with the spirit of renewal and enlightenment. And here, imagination is a significant creative process for deconstruction and enlightenment as well as upheaval in religiosity, religious rebelion, religious dissent.In this context, Muhidin and Syaifullah novels do not place religious life as a problem solver. Borrowing Goenawan Mohamad's definition that works that can be categorized as "religious literature" are works that "place religious life as a solution to problems", it appears that Muhidin and Syaifullah's novels cannot be called "religious literature" in the conventional sense. In this case, as a religiosity rebellion - where religiosity is defined as a philosophy of life or awareness of 'His breath' in everyday life, that is an awareness that is entirely personal and because it is personal, everyone has the right to sue, question, reject or deconstruct his own religious teachings.
\end{abstract}

Keyword : Manikebu; LEKRA; Payudara; novel; religiousity; santeri; Muslim; rebellion; reform.

\section{Introduction}

Modern literature is the art of language with a plurality of ideas, imagination and themes in it, whether it is poetry or prose, and it cannot be separated from language. To understand and appreciate literature, the reader must understand the language with all the possibilities of communication, meaning and aesthetics. TS Eliot even called literature (literary work) as a product of intellectual creativity with language as its medium. Language itself as a means of communicating ideas, ideas, emotions and human desires that are pure with a system that is consciously and intentionally used to build symbols. (E. Sapir, 1949: $13)^{1}$

\footnotetext{
${ }^{1}$ Regarding quotes and references in the 'introduction' section for this text, read Sapir, E., 1949, Languange, An Introduction to the Study of Speech, New york. Tentang Scholes, R., 1976, Structuralism in Literature, London : Yale University press. Lihat, Slonim, Marc, 1958, An Outline of Russian Literature, London : Oxford University press. See, Teeuw, A., 1983, Membaca dan Menilai Sastra, Jakarta,: Gramedia. Baca juga Wellek, R, And Warren, A., 1956, Theory of Literature, USA : New Haven, Harcourt, Brace* World Inc. Simak, Kleden, Ignas, 1981, "Kesusastraan Tidak Harus Menjadi Cermin Keadaan Masyarakat", in Tifa Budaya, editor, Kasijanto dan Sapardi Djoko Damono, Jakarta : Leppenas.. Lihat, De Jonge, A., 1973, Gogol, London : Oxford New College. See, Goenawan Mohamad, 1988, The Manikebu Affair : Lirerature and Politics in the 1960s, in magazine Prisma, the Indonesian Indicator No. 46. Baca, Foulcher, Keith, 1986, Social Commitment in Literature and the Arts, Centre of Southeast Asian Studies, Monash University, Clayton, Victoria. See, Herdi Nurwanto, 1985, Peranan Gogol Dalam Upaya Meningkatkan Martabat Manusia, Studi Kasus Novel Taras Bulba dan Shinel Karya Nikolai. V Gogol, Sebuah Tinjauan Strukturalisme, unpublsihed thesis, Fakultas Ilmu Budaya (Sastra jurusan Slavia seksi Rusia), Universitas Padjadjaran, Bandung
} 
In this context, Barthes argues that all types of social communication systems are languages and to avoid obscurity, he uses the term "code". In Barthes's view, all social codes, like language, have vocabulary. (Herdi, 1985: 7).

In this context, in literature, humans are "maker and reader of sign" (A. Teew, 1983: 6), to create and give meaning. Likewise, Saussure's view (as quoted by Scholes, 1976: 2). However, even though literature is identical in language, it is clear that there is a difference between language in literature (in this context prose) and everyday language. Wellek and Warren (1956: 24) with a transparent description as follows:

"That literary language is first of all to be the differentiated from the varied uses of every day. The resources of language are exploited much more deliberately and sistematically. In the work of a subjective poet, we have manifest a personality far more coherent..."

Thus, literature is the result of the author's creativity in the form of a coherent, personal, distinctive and stand-alone roundness. Of course the author in creation must be concerning the lives of humans and society of his time. However, literature will not be able to reflect all the socio-political situations and conditions of the society and its era, nor will it be able to reflect the entire conception of life and experience of its creator, because, once again borrowing the words Wellek and Warren (1956: 95):

"To say that literature mirrors or expresses life is even more ambiguous. A writter inevitably expresses his experience and total conception of life, but it would be manifestly untrue to say that he expresses the whole of life or oven the whole life of a given time-completely ang exhaustively..."

Therefore, Wellek and Warren argue that what the author imagines is very likely to be "The essence, the ambridement and summary of all history" of the society and the age of the literary creator concerned. Departing from these assumptions, various groups agree if Ignas Kleden (1981), for example, asserts that literature does not have to be a mirror of the condition of society. But in my opinion, literature can be involved and contextual with the socio-political reality of the era, although it does not have to be absolute. Because isn't literature not born of social vacuum, literature does not fall from the sky?

By revealing the history of the 1960s literature, the author really wants to emphasize that literature does not need to be taboo in voicing its people and times, but also does not need to feel inferior, shy or futile, if literature does not talk about social reality and times, but rather silence, vanity, mortality or being "another voice", even though it is the dissonant voices.

Literary sociology views literary work in relation to society, that the workings of the sociological approach are guided by the relationship of literary work with social groups, the relationship between people's tastes and the quality of literary works, as well as the relationship between the authors and their works. The literary sociology perspective according to Ian Watt is divided into 3 (three) namely (1) looking at literature as a social document, (2) looking at the author's social situation, (3) looking at the way the author uses his work in relation to socio-cultural conditions and historical events. ${ }^{2}$

Literature is a medium for documenting social problems. According to Wellek and Warren, sociology of literature talks about authors who question social status and social ideology. Literary sociology also displays the state of society and social facts in his work. So,

\footnotetext{
${ }^{2}$ Ian Watt.'s view and analysis, as quoted by Sapardi Djoko Damono, Sosiologi Sastra, Sebuah Pengantar, Depdikbud, Jakarta,1978
} 
it is clear that the sociology of literature deals with imaginary humans and the social problems that occur in society. ${ }^{3}$

According to Ian Watt, there are three main trends towards literary works. First, the author's social context. Social conditions in society affect authors in making literary works. Regarding the way the author gets a job, a professional in composing, the community intended by the author. Second, literature is a mirror of society. Literary works are displayed based on the state of society and social problems by the author in his work. Third, the social function of literature. There are 3 literary functions, namely (a) as a reformer and remover (b) as a mere entertainer (c) as a teacher of something by entertaining. ${ }^{4}$

\section{Review of Literature}

\subsection{About Moral Turmoil and Religiosity}

At the beginning of the Third Millennium, a novel published by Payudara by Chavchay Syaifullah (publisher of Melibas, 2005) and a novel by God, Let Me Become a Prostitute! (publisher of ScriPta Manent, 2005) Muhidin M Dahlan, who is busy talking about literary enthusiasts for being "another voice", the dissonant voices, the religious dissent. The two young authors appreciate both socialist realism and universal humanism, but do not want to enter into the "division' of the schools of literary art which has long been a" controversy ". And they do not need to carry the burden of history, when they themselves have not been born. ${ }^{5}$

Chavchay Syaifullah and Muhidin Dahlan grew up with instincts, worldview and their own zeal as "turbulent and seeking" individuals, "rebellious and inflamed" against religious and socio-cultural conventions resulting in ongoing tension in them. Reading the two novels, I am faced with an open text, in which the text becomes "another voice", the odd dissonant voices, as the religious dissent, which in expressing its content and meaning are so open that it allows our interpretation to lead to - following Gadamer - the fusion of the horizons, or leads to the fusion between the horizon of the text and the horizon of the interpreter ${ }^{6}$.

This understanding implies at the same time that on the one hand, the interpreter is aware of the richness of the text and, on the other hand, the text opens itself to the search for meaning. This reciprocal relationship allows the opening of the world of text that forms the trajectory of meaning for literary readers.

By trying to use Paul Ricoeur's hermeneutic category, namely appropriation or "selfunderstanding", an interpretation may help interpreters to better understand themselves, paradoxically, it must be brave to take distance. This distance taking is done with ideological and religious criticism and deconstruction. With the deconstruction of the interpreter invited to dismantle interests, motivations, goals that might have colored his interpretation. In this way, the interpreter is invited to be honest and open and thus is helped to understand the text

\footnotetext{
${ }^{3}$ Pandangan Wellek and Warren sebagaimana dikutip Sapardi Djoko Damono, Sosiologi Sastra, Sebuah Pengantar, Depdikbud, Jakarta, 1978

${ }^{4}$ Sapardi Djoko Damono, Sosiologi Sastra, Sebuah Pengantar, Depdikbud, Jakarta,1978

${ }^{5}$ Interview with Chavchay dan Muhidin, Jakarta, early April 2004.

${ }^{6}$ Haryatmoko, Sebuah Pengantar, dalam buku Mariana Amiruddin, Perempuan Menolak Tabu, Hermeneutika, Feminisme, Sastra, Seks, Pustaka Melibas,2005.See, Paul Ricocur, From Text to Action: Essays in Hermeneutic II, Northwestern University Press, Evanston Illinois, 1991
} 
better. That hermeneutics is not only a theoretical method, but can be applied and enriches the understanding of literature. With this hermeneutic method, we can try to understand texts that are not present from all writers but instead have links and links with the text horizon itself so that the 'fusion of horizons' occurs.

In Chavchay Syaifullah and Muhidin Dahlan's novels (both young writers from Islamic/ santri pesantren backgrounds) there are moral upheavals and rebellions and religiosity which is very likely to provoke protest, anger and demagogy in the religious community and their communities who read their novels. So that they (the two young writers) might be considered as "eccentric", "eccentric" or even labeled "“ at heretical 'or even" apostate "(leaving religion or deviating from religious teachings).

In Chavchay Syaifullah's note there is a need for us to point out here that the past in the realm of literature, he said, has ever been such a tense crisis as reflected in the short story of Langit Makin Mendung by Kipandjikusmin and short story Collapse of Our Surau by A.A. Navis which caused social upheaval. Even HB Jassin in the story of Langit Makin clouded, was dragged to court and protested by 'religious groups' and 'believers' who felt disturbed by the work. Then Chavchay also noted that in other times the case of the Lord's novel appeared, Let Me Become a Prostitute! by Muhidin M. Dahlan. This novel has even been opposed by Muslim activists, including the Muhammadiyah youth in Yogyakarta and rejected by all Gramedia bookstores. Maybe because Gramedia was worried that it would lead to cases such as the tabloid Monitor led by Arswendo Atmowiloto, which had been raided, raided and ransacked by the rampage of the Muslim masses.

In the Indonesian context, we are truly stunned to see the various tensions between the literary creative process and the struggle to maintain faith by religious circles. Why should I be stunned? Because, as far as we observe, cases that include the tension of art and religion, almost rarely end with the existence of a meeting point where both parties are able to complete it in a "final and brilliant", moreover epistemically reaching the points of "theoretical agreement" which is final. Usually what happens is that one wins and one loses, even some of them are imprisoned, forgiven, characterized or tortured. Even if it is finished without all of that, it is usually finished with a "pseudo" handshake that has a grudge or at least a "big question mark" 7

It is almost in vain to expect a kind of "general convention" in which the religious and literary parties are aware of the code of ethics of art and religion, so that there is no need to wait for futile tensions that stick to the public.

So far in Indonesia there has been no art and religious dialogue, the continuity of which is not only at the elite level, but also at the community level. If there is dialogue, somehow the pattern of dialogue, but clearly must be more deeply rooted and more detailed, will undoubtedly be of benefit to the public interest. If only we had only been involved with 'school artists' and 'ahlul kitab', now it must be more entrenched to pop art workers and religious fighters who acted and were angry in the field. The author sees that Chavchay Syaifullah's principle is relatively firm that every outcome of his thoughts must be fought for. Just like Pramoedya Ananta Toer said, which he often articulated, "" The truth does not come from the sky, it must be fought to be right." And of course it is the public who finally assesses the results of the thinkers' thoughts and struggles.

\footnotetext{
${ }^{7}$ Chavchay Syaifullah, "Kemelut Seni dan Agama", artikel dalam kolom Ide, Koran Tempo Mei 2005. Ibid
} 


\subsection{Deconstructing}

Until the beginning of the third millennium, Chavchay Syaifulah and Muhidin M. Dahlan saw that the messages of religion and ideology in the early days of their presence were more inclined to liberation efforts, in their history now tended to be swallowed up by historical processes that distorted them. Christianity / Catholicism, Islam, Hinduism and so on, as well as ideology of socialism, capitalism and others, are now confronted with open and hidden crises in the midst of the world and human beings who are changing. Syaifulah and Muhidin saw the same thing where understanding and interpretation / interpretation of religion and ideology experienced open and hidden crises. The crisis arises because, in its history, religion and ideology turned into an institutional "hierarchy" in which the ruling is a certain "authority" that has the right to say about certain truths in the name of "Absolute Authority", be it God, the ruling party, class literati, alama elite or others.

For both authors, the biblical texts of religions and ideological texts which originally contained universal messages, were then standardized through certain interpretations that were "formalized" by religious and ideological institutions, to then be "taught" to the people, or the community they are something that is finished, complete and impervious to criticism. The officialization (initialization) finally had fatal consequences: religion lost its prophetic impression as a "religion of liberation", and ideologization resulted in dehumanization. ${ }^{8}$

Dahlan saw that the messages of religion and ideology in the early days of his presence which were more inclined to liberation efforts, in their history now tend to be swallowed up by historical processes that distort them. Christianity / Catholicism, Islam, Hinduism and so on, as well as ideology of socialism, capitalism and others, are now confronted with open and hidden crises in the midst of the world and human beings who are changing. Syaifulah and Muhidin saw the same thing where understanding and interpretation / interpretation of religion and ideology experienced open and hidden crises.

The crisis arises because, in its history, religion and ideology turned into an institutional "hierarchy" in which the ruling is a certain "authority" that has the right to say about certain truths in the name of "Absolute Authority", be it God, the ruling party, class literati, alama elite or others.

For both authors, the biblical texts of religions and ideological texts which originally contained universal messages, were then standardized through certain interpretations that were "formalized" by religious and ideological institutions, to then be "taught" to the people, or the community they are something that is finished, complete and impervious to criticism. The officialization (initialization) finally had fatal consequences: religion lost its prophetic impression as a "religion of liberation", and ideologization resulted in dehumanization.

When religion experiences excessive processes of institutionalization, what happens is

\footnotetext{
${ }^{8}$ The oficvialization of religion (read: Islam) was heavily criticized by Arkoun, an avant-gardist Muslim thinker from Algeria who now lives in France. In this connection, Arkoun enthusiastically uses Derrida's deconstruction method. See, Mohamad Arkoun, "Kaifa Nadrusu Alfikral Islamy", in Mohamad Arkoun, Tarikhiyyatul Fikril 'Araby Al-Imlamy, tr. Hasheem Saleh, Lebanon: Markazul Inma Al-Qaumy, 1986, p. 1248. Criticism of the initialization of ideology in the context of modern Indonesian politics, see Mohamad Arkoun, "Kaifa Nadrusu Alfikral Islamy", dalam Mohamad Arkoun, Tarikhiyyatul Fikril 'Araby Al-Imlamy, tr. Hasheem Saleh, Lebanon : Markazul Inma Al-Qaumy, 1986, hal. 12-48. Criticism of the initialization of ideology in the context of modern Indonesian politics, see, Ulil Abshar Abdalla dan Herdi Sahrasad, Mencoba Dekonstruksi atas Agama dan Ideologi, esai, majalah Ulumul Quran, 1994.See, Madan Sarup, "An Introduction to Post-structuralism and Post-Modernism" (New York: Harvester Whitesheaf, 1988).
} 
the silencing of the wealth of interpretations of the Scriptures. Apart from the official interpretation recognized by the authorized institution, it is impossible for other interpretations to be acknowledged. The Scriptures which were originally open to all interpretations, silenced their voices to only "read one interpretation" only (monophonic exegesis). ${ }^{9}$

Communities of religions that are outside the area of "official" interpretation will be labeled apostates or heretics. If this is the case, then the historical caricatures were born such as the inquisition during Al-Makmun (for the Islamic case) or during the Reformation (for the Christian case). In fact, ironically, we can still witness that caricature in Indonesia today, for example - to refer to the most recent example - a "hot" polemic around Islamic reform launched by Nurcholish Madjid or a ban on bookstores selling Muhidin M Dahlan's novels.

The whole shows that when religion has become an institution monopolized by certain authorities, it will lose its character as religion. "liberator", but on the contrary, as a judge who distributes verdicts to heretics or misinterpretation. This kind of thing motivates Syaifulah and Muhidin to do 'religious reluctance and rebellion' in their novels to find and rediscover 'prophetic messages' of religion and ideology through the multi-interpretive literary area.

Chavchay Syaifulah and Muhidin also see this institutionalizing religion phenomenon occurring in all religions in the world. If all this time we have witnessed a war, or at least a hot conflict, between religions, then actually, those who work there, for the most part, are the interests of religious "institutions" that maintain their interests, not the consciences of people who are often better able to read "truth" is something that is "beyond the religion as institution"; something that goes beyond religion as an institution; religion as a representation of the hidden truth in the "cleanest earth of conscience" of human beings who since its birth brought the nature of truth as religions once demonstrated (in Islam, for example, there is a hadith: istafti qalbaka - ask for guidance in your heart).

By considering the perspective mentioned above, it is natural and reasonable if both Muhidin and Syaifullah are from santri backgrounds, both of which deconstruct conventional Islamic literature, as well as deconstruction of religious and ideological texts, an act of "religiosity rebellion" in the literary field, an area of fiction and imagination called Gogol as the area of creation. ${ }^{10}$

9 Borrowing Ulil Abshar Abdalla's language, this is what Arkoun, borrowing Derrida's concept, calls logocentricism (al 'aqliyyatul markaziyyah). Logosentrieme, for Arkoun, is the assumption of the existence of "Great Reason" (Logos) which is authorized to monopolize an interpretation of a particular text. This is what ultimately creates binary opposition between what Arkoun, in his various books, is referred to as "l'impense discourse" dan "penso' discourse" (Al-Khithabul La-Mufakkar fihi dan Al-Khithab Al-Mufakkar fihi -diskursus yang boleh dipikirkan dan yang tak boleh dipikirkan). Baca Muhammad Arkoun, Aina Huwal Fikrul Islamy Al-Mu'ashir, Hasheem Saleh, Beirut Darus Saqi, 1993.

${ }^{10}$ Interview with the ypung novelists : Muhidin Dahlan dan KH Chavchay Syaifullah, in Jakarta medio MayJune 2005. Muhidin Dahlan is an alumnus of the Yogyakarta Hasyim Asyari Krapyak Islamic Boarding School, he is also a former HMI and PMII activist, two influential Islamic Student organizations. With the background of Muhidin's court, for the general public, it seems rather surprising if he becomes a strong writer with 'religious rebellion' in his novel which turns out to be reprinted in a short time. About Syaifullah, these young writers studied art and religion at Daar el-Qolam Islamic Boarding School, Banten, at Raudhah elHikam Islamic Boarding School, Cibinong and Rabithah Ali Alamsyah, Mecca-Saudi Arabia. In 2004, he completed his studies at the Driyarkara School of Philosophy, Jakarta, which he studied for 9 years. The novel is considered public 'problematic' titled Payudara (2004). 
In the Balaghah books that Syaifullah learned in the pesantren first, there are indeed many studies of Arabic literature related to the moral and spiritual guardian of Islam. Starting from literature that uses metaphors in the form of ar-rajaa and al-munaa, up to literary works that "approach" the aesthetic verses of the Qur'an in terms of its tarkiib and the greget character that feels muqayyad. Also in the Mahfudzat poems whose literary levels need not be doubted. Starting from the saying of Man Jadda Wa Jada arrived at Saafir Tajid id Iwaadhan .... from Imam Syafe'i.

Is this type of Arabic literature called Islamic literature? Or is Islamic literature as written by Rumi or Hamzah Fansuri? Or more superficially, is Islamic literature a literary work written by only Muslims? Not. In Syaifullah's view, we cannot rashly formulate Islamic literature. This needs to be taken into account. For example, let's say we agree that Islamic literature is a type of literature written by Muslims and about something related to Islam, whether Islam as a religious institution or even as a value system.

If this is the case, a simple question will be asked immediately: why is the Muhidin M. Dahlan novel entitled God, Let Me Become a Prostitute! sabotaged and criticized by Muslims themselves. Even though the novel was written by Muhidin who is an Islamic with a background in his personal life long at the Islamic boarding school, talking about Islam as well, and inviting his readers to Islam deeper and so on. Only the starting point is different. ${ }^{11}$

With the terror that ambushed him, Muhidin frightened himself when he wrote his latest novel, Bad News From the Sky: The Wound of Love for the Search of God. Judging from the content of the story, it's clear that this novel is more interesting than the past. In addition to the erudition of Muhidin more widely seen, he also seemed to dive into the teachings and myths in Islam more freshly, among others because of tugging the teachings of major Islamic thinkers such as Imam Ghazali, Al-Hallaj and Ayn al-Qudat, and 'earth 'the angel Gabriel with all the news of the heavens. In other words, the literary and civilizational dialogue of Islam has been resurfaced.

Just because Muhidin had been terrorized throughout 2004 with regard to his novel which tells about Nidah the prostitute's Muslimah, the presence of this next novel is said to be limited, and his intention of the Bad Kabar novel from Heavens would be sold from friends to friends only. How tragic is this young Islamic intellectual, said Chavchay Syaifullah.

\section{Discussion}

\subsection{Deconstruction and Reinterpretation About Mecca and Medina}

Literature is indeed multi-interpretive and very fluid, so it can be realized in many variations of writing. Islamic struggle is no longer necessary, but it is obligatory for every Muslim who follows the hadith (sayings, actions and daily life) of the Prophet Muhammad ${ }^{\mathbf{1 2}}$. Especially through the hadith that reads 'Innamaa Bu'itstu Liutammima Makaarimal Akhlaqi', we increasingly know that improving the morality of the ummah in many fields of struggle, needs to be realized including in the field of literature. Only those writers plus Islamic moral fighters also need to be aware that literary media is not as clearly predictable, so that their literary writers suddenly feel guilty if they do not describe the good and evil version of Islam. According to Syaiful's reinterpretation, this is important, at least so that literature is not

\footnotetext{
${ }^{11}$ Talks with Chavchay Syaifullah, ibid. Lihat juga esai Chavchay Syaifullah yang lain, "Islam Yes, Sastra Islam So What".

${ }^{12}$ Interview with Chavchay Syaifullah, ibid
} 
merely seen as a means of dictating one teaching. Moreover, teachings that can no longer be offered.

Beyond the divine role of God, Abu Jahal and Abu Lahab are examples of two people who are not interested in Islam, because Islamic nuance at that time was not yet able to absorb the reality of the ignorant society at that time. In addition to the verses of the Qur'an which are indeed poetic, Islamic warriors at that time were not strong enough to face the literary tradition of the Quraysh tribe which had been famous. In short, Islamic warriors at that time still dominated the Islamic ethical side, not aesthetically.

Sensitivity to literary reflection is lacking. Poetry or literary confrontations that often take place around the rakyat people's market 'often do not show the greatness of Muslims who are indeed not many in number. Another case after migrating to Medina. The dialogue of the Muhajirins and the Ansar has opened a new chapter of Islamic civilization. The bitter experience that plagued the Muhajirites in Mecca has touched on the esoteric aspects of Islamic da'wah. Plus the inclusiveness of the Yasrib community at that time, opened new horizons of how literature was also open to dialogue. Of course, even dialogue with new morality. Even with an odd new value.

\subsection{Symbolic Marriage of Satan and Humans}

In this context, we need to look at the obsession as a "movement person" or activist, which is very visible in the internal relations of the characters portrayed. Marriage of demons and humans, namely Isabela and Bayu is not shown to be just a strange ritual. The author also made it a "political marriage" with the mission that the devils and humans not be suspicious of each other which was then packaged in the jargon "Cultural Revolution". "Just imagine you, when humans can understand Satan and even Satan can understand humans," (p.134)

This spirit is funny, because the cultural revolution that is displayed is not at all serious, let alone rational. Imagine, Bayu and Sakti who stray into the grave because of starvation, want to eat fried rice, meet a female ghost named Isabela, who suddenly protects Bayu completely from the siege of zombies.

Isabela protected Bayu extraordinarily even Bayu was ordered to follow all the movements of the devil, walking leaping like Chinese ghost films. Then when Bayu was driven home by the demon Isabela, they met people on the market and these people urged Bayu and Isabela to get married. Suddenly the masses arrived and like a political campaign, the president of the cultural revolution named Martin was chosen to witness their marriage. Funny, indeed. The enthusiasm of political activists here is felt, the authors describe it as the atmosphere of a two-party coalition campaign ahead of the election. Being absurd, because everything is done without the common thread, and by demons and humans. Bayu sometimes asks himself or Sakti, "I don't understand why this fact happened to me. I have never thought in my whole life that I would marry a demon, "whispered Bayu (p.103). And Sakti actually replied, "You are a hero who reconciles human relations with Satan, '(p.103)

Even the spirit of women's emancipation is also here. The figure of Isabela, for example, is truly defended by Sakti, with a political nuance: Isabela is a great woman. He is a female human demon who has been firmly using his ratio. Sakti wants to say that women are not all creatures full of a sea of feelings, and that is what makes women considered unable to become leaders. That Isabela was not ahistorical, it was the history of the Cultural Revolution itself, it inspired a strange revolution, the revolution of crazy people. Another unique thing is that when Sakti returned to the cemetery that apparently there was no man named Pak Kubri, 
and even the location of the tomb was guarded by worms and maggots, there was a tomb that had just been made, and there seemed to be a new body in it that called - call Sakti. Above the grave is a piece of poetry. Funny dialogue, Sakti says, God! Is it true that the dead was Abdul Kubri? Then, who buried it? Is it possible to bury Sapardi Djoko Damono? "

As a result, the fusion which is not merely a physical-biological fusion creates a radical event that is complicated and damaging and destroys the order and purity of the concepts of humans and demons. Sakti, Bayu, Payudara, and Isabela also fought to find a new formula about the world order and their existence. Philosophical reasoning is inevitable, erupting, and exploding here and there, sparking a kind of revolution in another perspective on the existence of self and its world. Sakti and Bayu become half devil humans. Breasts and Isabela become demons of half human.

Thick and barking philosophicalism is the main element that fulfills this novel. Humans and demons who are united, lost, and shoulder to shoulder to find their essence and existence are about to inhabit another world and they have not yet discovered it or experienced it. They fight with each other and they fight within themselves. They are forced to knock their world again before smelting occurs to reassess and find their existence and nature. But they cannot fully understand and understand the existence and nature of their humanity and demons. And they are increasingly becoming unable to find existence and essence in their fusion. The struggle was unavoidable and thundered the story situation.

The novel's plot moves randomly between the real world and the world in Sakti's mind, moving in a real and surreal world that is twisting together. The choice of this plot is a kind of effort to adjust to the spirit of the novel which is full of tumultuous struggles to find the existence and nature of humanity and demons. The shaking disrupts madness and sanity, squeezes each other, intervenes, provokes one another. A variety of rational, religious, mystical thoughts and events, and especially those that smell dominant in philosophy and scatter.

Although philosophy is dominant, this novel is not a philosophy-treatise. The existence of this work is a novel and not a philosophy-treatise. Because the author's intention is to make this work as a literary work in the form of a novel as acknowledged in the introduction to his work and this intention is evidenced by the appearance of the elements contained in his work: the creation of storytelling forms, creating characters and their statements, as well as events events that echo complex voices in a complete and solid composition so as to be able to enrich the understanding of the existence and nature of the problems they carry out.

Noteworthy, philosophically or literally, this novel contains the spirit of 'rebellion religiosity' as described by the marriage of demons and humans, demons and humans allied in sincere fusion, so that the life order and outlook of their world changes. Here religious and social norms and values such as between good and bad, heaven and hell, black and white, become increasingly blurred, dissolve and multiply into new perspectives and values in the author's imagination and fiction.

\section{Moral Upheaval and Religiosity}

\section{Conclusion}

There are several views in this matter among Muslims: First,. The first clear connection between literature and religion is the fact that many literary works are expressions of one's appreciation of God. Secondly, The second relationship is the use of symbols in the form of vocabulary that has been commonly used in religious life as signs in literary works.Third, in 
creating literary works, many authors continue to make religion a benchmark, while other authors consider literary works to be free of religious influences. This difference of opinion resulted in differences of opinion among writers and literary experts.Fourth, readers of literary works use their horizons of hope in understanding literary works. Readers who are oriented towards religion, of course, expect that literary works do not oppose religion (in the sense of formal religion) so that they will respond negatively to the religion through literary works. Fifth. However, it can be said that the author is religious or not, his work must still contain aesthetic values and in accordance with literary conventions. Literary society that will provide an assessment because the greatness of literature is determined by criteria other than aesthetics, such as religion. Sixth. Literature, as a scientific knowledge, has the role of providing scientific explanations regarding the relation of literature to other fields outside of literature, such as religion.

The relationship between literature and other religions that should not be forgotten is the relationship of ignorance that becomes the discussion of the semiotic world. In semiotic theory, literary works are seen as meaningful sign structures. Semiotic theory departs from the view that social phenomena and culture are signs. The sign has two aspects, namely markers and markers. Markers are formal forms that mark something, while markers are those marked with markers. An example is the word "mother" which is a marker for "the person who gives birth".

We think the meaning of "moral upheaval and religiosity" and the deconstruction of the meaning of religious teachings in Syaifullah and Muhidin's novels must be captured in their essence and substance to deconstruct Islamic understanding and ideology that has been frozen, hierarchical and obsolete. Of course both Muhidin and Syaifullah do not pretend to be 'essentialist' and 'naïve' and 'banal' substantial. However, their novels are a quest and struggle that is not final.

There will be more of their novels that are very likely to be colored by the "turbulence of religiosity or rebellion of religiosity" within the boundaries of the fantasy, epistemology and imagination they have. However, it is the search and struggle process - no matter what achievements they have achieved - which we must appreciate as an effort to make a breakthrough in the freezing and chaos of interpretations of religion and ideology.

As writers, both of them make a search so that literature does not merely speak the norms, conventions, traditions and things that are considered given as teachings of truth. Rather, it articulates "other voices", other worlds, the dissonant voices, the religious dissent. The religious teachings that have experienced institutionalization / initialization have been sued again, in the upheaval and rebellion of "religiosity" by Muhidin and Syaifullah within the limits of the imagination, fantasy and epistemology that they have, so as to produce a text that is "against prevalence and convention". the other voice, the dissonant voices are odd, the religious dissent is in literature.

Religiosity is not understood as a spirit and religious teachings which they consider to be frozen, given, which must be obeyed and aminied, but rather dismantled and deconstructed with reason in a never-ending search process, which is full of twists and madness, which in the language of Goenawan Mohammad it is referred to as sincerity and commitment to the literary world with a stubborn love. We believe that the presence of Syaifullah and Muhidin has enriched Indonesian literature, and in the long run it will not be a "thorn in the flesh" for our intellectual repertoire, nor will it be a "spiked rose" in modern Indonesian literature, borrowing Harry Aveling's language. 
If we look at the development of Islamic intellectuals, what is articulated by Syaifullah and Muhidin in an Islamic perspective will raise the spirit of literary deconstruction / renewal in the Islamic community. And this parallels the emergence of Islamic reformers.

Most Muslim reformers, since al-Thahtawi, Muhammad Abduh, Ali Abd al-Raziq, to Muhammad Arkoun and Nurcholish Madjid, are intelligentsia who believe that Islam can change and adapt to circumstances. For them "reformed Islam is still Islam." Some sympathetic Western writers such as John L. Esposito, Leonard Binder, and John Voll, believe that Islam can accept democracy, liberalism, and modern concepts that come from outside Islam, insofar as they do not conflict with Islam. ${ }^{13}$

For these Islamic reformers, there are no teachings or Islamic doctrines that are fully enduring. He changes and adapts to the demands of the times and circumstances. As a universal religion, one of the basic capital of Islam to adjust is change. ${ }^{14}$ If Islam rejects change, then actually it is against and contrary to its own nature as a universal religion. In this context, the case of Muhidin and Syaiful's novels can be included in the context of Islamic renewal in the field of literature. At least that is my interpretation (and pledoi) of "moral upheaval and cultural religiosity and deconstruction" in the work of two young novelists at the beginning of this third millennium. Do you agree? If there is something wrong, forgive us.

\section{References}

Sapir, E., 1949, Languange, An Introduction to the Study of Speech, New york. Scholes, R., 1976, Structuralism in Literature, London : Yale University press. Slonim, Marc, 1958, An Outline of Russian Literature, London : Oxford University press. Teeuw, A., 1983, Membaca dan Menilai Sastra, Jakarta,: Gramedia.

Wellek, R, And Warren, A., 1956, Theory of Literature, USA : New Haven, Harcourt, Brace* World Inc.

Kleden, Ignas, 1981, "Kesusastraan Tidak Harus Menjadi Cermin Keadaan Masyarakat", in Tifa Budaya, editor, Kasijanto dan Sapardi Djoko Damono, Jakarta : Leppenas.. De Jonge, A., 1973, Gogol, London : Oxford New College.

Goenawan Mohamad, 1988, The Manikebu Affair: Lirerature and Politics in the 1960s, in Prisma, the Indonesian Indicator No. 46. Baca, Foulcher, Keith, 1986, Social Commitment in Literature and the Arts, Centre of Southeast Asian Studies, Monash University, Clayton, Victoria.

Herdi Nurwanto, 1985, Peranan Gogol Dalam Upaya Meningkatkan Martabat Manusia, Studi Kasus Novel Taras Bulba dan Shinel Karya Nikolai. V Gogol, Sebuah Tinjauan

\footnotetext{
${ }^{13}$ Luthfi Assyaukannie, "Islam yang Terus Berubah" Jaringan Islam Liberal, situs islib.com pertengahan September 2004. See, New Statesman edisi September (13/09/2004) ) who made the main report on Islam entitled: "Can Islam Change?" (Can Islam Change?). This seemingly simple question actually saves big problems and becomes a heated debate among intellectuals and scholars, both Muslim and non-Muslim.

${ }^{14}$ In terms of Islamic reform there have been various controversies. For orientalists like Samuel P Huntington and Daniel Pipes, they think that Islam is a religion that is stagnant, frozen and cannot change. Both argue that the absence of democracy in most of the Islamic world shows the attitude of Islamic resistance to change. Pipes specifically points to innovation in Islam as a key concept for rejecting change. Likewise Orientalist Lord Cromer, like Huntington and Pipes, also argues that Islamic reform efforts are not something Islamist. "Reformed Islam," he said, "no longer Islam." (Islam reformed is Islam no longer).
} 
Strukturalisme, tesis sarjana tak diterbitkan, Fakultas Ilmu Budaya (Sastra jurusan Slavia seksi Rusia), Universitas Padjadjaran, Bandung.

Keith Foulcher, Social Commitment in Literature and the Arts, Centre of Southeast Asian Studies, Monash University, Clayton, Victoria,1986,pp 22-26.

Ian Watt.'s view and analysis, as quoted by Sapardi Djoko Damono, Sosiologi Sastra, Sebuah Pengantar, Depdikbud, Jakarta, 1978

Sapardi Djoko Damono, Sosiologi Sastra, Sebuah Pengantar, Depdikbud, Jakarta,1978

Sapardi Djoko Damono, Sosiologi Sastra, Sebuah Pengantar, Depdikbud, Jakarta,1978

Haryatmoko, Sebuah Pengantar, dalam buku Mariana Amiruddin, Perempuan Menolak Tabu, Hermeneutika, Feminisme, Sastra, Seks, Pustaka Melibas,2005.

Paul Ricocur, From Text to Action: Essays in Hermeneutic II, Northwestern University Press, Evanston Illinois, 1991

Chavchay Syaifullah, "Kemelut Seni dan Agama", artikel dalam kolom Ide, Koran Tempo Mei 2005.

Interview with Chavchay dan Muhidin, Jakarta, early April 2004.

Mohamad Arkoun, "Kaifa Nadrusu Alfikral Islamy", in Mohamad Arkoun, Tarikhiyyatul Fikril 'Araby Al-Imlamy, tr. Hasheem Saleh, Lebanon: Markazul Inma Al-Qaumy, 1986, pp. 12-48.

Mohamad Arkoun, "Kaifa Nadrusu Alfikral Islamy", dalam Mohamad Arkoun, Tarikhiyyatul Fikril 'Araby Al-Imlamy, tr. Hasheem Saleh, Lebanon : Markazul Inma Al-Qaumy, 1986, pp. 12-48.

Ulil Abshar Abdalla dan Herdi Sahrasad, Mencoba Dekonstruksi atas Agama dan Ideologi, esai, majalah Ulumul Quran, 1994.

Madan Sarup, "An Introduction to Post-structuralism and Post-Modernism " (New York: Harvester Whitesheaf, 1988).

Muhammad Arkoun, Aina Huwal Fikrul Islamy Al-Mu'ashir, Hasheem Saleh, Beirut Darus Saqi, 1993.

Interview with the ypung novelists : Muhidin Dahlan dan KH Chavchay Syaifullah, di Jakarta medio May-June 2005.

KH Chavchay Syaifullah, Payudara (2004).

Chavchay Syaifullah, "Islam Yes, Sastra Islam So What".

Mariana Amiruddin, "Payudara": Kegilaan sebagai Penyembuhan, Sinar Harapan, 23 October 2004.

Binhad Nurrohmat, Sentuhlah Novel Payudara Itu, Media Indonesia, 25 maret 2005.

Mariana Amiruddin, "Payudara": Kegilaan sebagai Penyembuhan, Sinar Harapan, 23 October 2004.

Binhad Nurrohmat, 'Sentuhlah Novel Payudara Itu', Media Indonesia, 25 maret 2005.

Asep Sofyan (Media Indonesia, 13/2/2004),

Chavchay Syaifullah (Media Indonesia, 20/2/2005),

Ahmad Nurullah (Media Indonesia 27/2/2005),

Asep Sopyan (Media Indonesia, 13/3/2005) dan Binhad Nurrohmat (Media Indonesia 20/3/12005).

Binhad Nurrohmat, Sentuhlah Novel Payudara Itu, Media Indonesia 20 March 2005

Rohani Syawaliah in her review of this novel, 'Review: God, Let Me Become a Prostitute,' October 3, 201, as a blogger, writes that public condemnation of Muhidin was clearly 
wrong and wrong.http://www.honeylizious.com/2011/10/book-review-tuhan-izinkanaku-menjadi.html.diakses 12 October 2012.

Hidayatullah, majalah, 25 June 2005

Rahmat Djoko Pradopo, Pengkajian Puisi. Yogyakarta: Gadjah Mada University Press,1987 Luthfi Assyaukann September 2004.

New Statesman edisi September (13/09/2004 